\title{
Proměny konceptu zoo jako reflexe vztahu člověka a př́rody
}

\section{Lukáš Nekolný}

Envigogika 16 (1) - Recenzovaná články / Reviewed Articles

Published/ Publikováno 6. 6. 2021

DOI: $10.14712 / 18023061.618$

\begin{abstract}
Abstrakt
V průběhu historie lidstva se vztah k přírodě a zviřatům měnil. Zoo jsou typickým sociálním konstruktem, který tento vztah vyjadřuje a reprezentuje. Tento článek se proto věnuje reflexi jejich vývoje a diskuzi současného stavu. Dlouhou dobu byly zoo antropocentrickým symbolem lidské kontroly nad př́rodou. Se změnami společnosti se však měnily jejich role a podoba. Zoo 19. století k dosavadní zábavě a rekreaci přidaly výzkum a vzdělávání, což bylo ve 20 . století rozšířeno o ochranu prírody. Ve vědecky řízených zoo aktuálně dochází ke klíčovému propojování těchto funkcí - v ideálním př́ípadě do ochranářského edutainmentu. Vznikají zážitkově a ekocentricky pojaté areály, $v$ nichž mizí bariéry a návštěvníci se vnořují do prostředí sdíleného se zviřaty. Záchrana druhu je nově pokládána za důležitější, než význam jedince. Aktuální stav je nicméně reflexí koevolučního vývoje, který se eklekticky zaznamenává do podoby zoo a zachycuje i mnohé z minulosti, nejen nejnovější trendy.
\end{abstract}

\section{Abstract}

Throughout human history, humanity's relationship to nature and animals has changed. Zoos are a typical social construct that expresses and represents this relationship. Therefore, this article reflects on their development and discusses the current state. For a long time, zoos acted anthropocentrically as a symbol of human control over nature (e. g. cages). With the changes in society, the zoo roles and appearance have changed. The $19^{\text {th }}$ century zoos added research and education to their existing entertainment and recreation objectives, which were expanded to include nature conservation in the $20^{\text {th }}$ century. In scientifically managed zoos, these functions are currently being integrated - ideally into conservation edutainment. Adventure and ecocentric exhibits are created, in which barriers disappear and visitors immerse themselves in the environment of kept animals. The conservation of species is newly perceived as more important than that of an individual. However, the current situation reflects co-evolutionary developments, which reflect the past, not just the latest trends.

\section{Klíčová slova}

Zoo; antropocentrismus; ekocentrismus; antropomorfismus; koevoluce; eklekticismus; transformace

\section{Key words}

Zoo; Anthropocentrism; Ecocentrism; Anthropomorphism; Co-evolution; Eclecticism; Transformation 


\section{Úvod}

Aktuální podoba a charakteristiky všech fenoménů jsou podmíněny historickým vývojem. Společnost se za poslední staletí intenzivně pozměnila, prošla vývojem z preindustriální přes industriální na postindustriální společenství (Urban 2017), v průběhu čehož se vyvíjely mnohé náhledy na svět. Jedním z nich bylo a je vnímání živočišné říše, která vždy člověka lákala a zajímala.

Antropocentrismus je způsobem myšlení (etickým přesvědčením) vycházejícím čistě ze zájmu o člověka. Nahlížení na svět je $v$ tomto př́padě ryze lidskou perspektivou. Lidé jsou bráni jako příslušníci nejvýznamnějšího druhu na Zemi (Probyn-Rapsey, 2018), nebot' "člověk je středem i konečným cílem světa a vesmíru" (Linhart a kol., 2004, s. 36). Př́rodní prostředí je ignorováno, nanejvýš je chápáno jako pozadí, tedy lidstvo existuje separovaně od př́rodního světa. Jiné organismy nemají vnitřní (objektivní) hodnotu. $V$ průběhu času se vyvinulo více podob, resp. intenzit antropocentrismu podle toho, jak zásadně ignorují prírodu (Barnhill, 2010). Právě tento přístup je dlouhodobě stěžejní součástí západní kultury a myšlení (Rae, 2014). Všichni klasičtí západoevropští filozofové (např. Descartes, Kant) byli antropocentristé. Zmíněný přístup je typický i pro monoteistická náboženství včetně křestáanství. Antropocentrismus začal být časem kritizován z toho důvodu, že člověk nemůže vědět, jaké jsou potřeby jiných druhů (Kopnina, 2018).

$\checkmark$ protikladu $\mathrm{k}$ antropocentrickým pojetím jsou ekocentrické a biocentrické přístupy (Rae, 2014). Soustředí se na prírodní svět, a to včetně lidí viděných z tohoto úhlu pohledu, nebot' ti jsou pak jeho integrální součástí. Př́stupy těchto dvou směrů se však mohou vzájemně lišit. Biocentrismus zahrnuje biotickou složku - živou přírodu (organismy: zejména živočichy a rostliny) - a zdůrazňuje individuální organismy. Oproti tomu ekocentrismus zahrnuje i abiotické faktory včetně celých ekosystémů. Jedná se o více komplexní př́stup, proto bývá někdy $v$ kontextu nahlížení na realitu ztotožňován s pojmem holismus (Barnhill, 2010).

Vztah lidstva (společnosti) k přírodě a zviŕratům se tedy měnil, a to nejen $v$ teoretické rovině. Nejprve byli živočichové pro člověka objekty lovu, následně docházelo u vybraných (užitečných) druhů k jejich shromažd'ování, chovu a domestikaci. Když vznikala první města, vlivem zájmu o divokou přírodu se prvně objevovaly nové sociální konstrukty - "sbírkové instituce", mezi nimi botanické a zviŕrecí parky. Ve starověkých impériích Egypta i Číny existovaly oba tyto typy institucí. Chov pro obživu i potěšení a rovněž vystavování zviŕ̌at má tradici již několik tisíc let (Mizicko \& Bell, 2001). Botanické zahrady však byly vždy bliže $k$ vědě, medicíně a výzkumu, nebot jejich vznik byl zpravidla spojen s univerzitami (Hoage \& Deiss, 1996). Zoo - expoziční areály, v nichž jsou vystavována živá zviŕata - se staly vědeckými institucemi později (Borgards, 2016). Sbírky zvířat byly dlouhou dobu vnímány jako místa zábavy a kabinety kuriozit, na nichž se prezentovala moc majitele. Od konce 18. století se začaly přidávat další role zoo - výzkum a vzdělávání (Steinecke, 2009).

Industrializace a urbanizace industriální éry s sebou od konce 18 . století a zejména $v 19$. století přinesly zvýšenou potřebu prírody a zároveň kulturních institucí v nově budovaných městech. Kontakt města s př́rodou (do té doby od člověka nikdy tak výrazně oddělenou) přinesly mj. tzv. moderní zoologické zahrady, jejichž pojetí se dále průběžně vyvíjelo. Tyto sociálně konstruované areály v sobě zahrnují další etapu vnímání živočišné řiše člověkem. Původně se jednalo o oázy odpočinku od rušného městského života (Grazian, 2017). Zároveň se zviŕata v 19. století stávala předmětem zkoumání, byla vytvářena taxonomie, podle níž byla také zvírata vystavována (Rabb, 1994). Od druhé poloviny 19. století tyto zviŕrecí parky přestávaly zůstávat místem přistupným pouze úzce vymezené skupině lidí. Začínaly se transformovat na veřejné prostory - veřejně přístupná zařízení pro rekreaci a poučení (Benbow, 2000). Průběžně docházelo k rozvoji dalších technologií, dopravy, a také ke změnám ve společnosti: ve 20. století hlavně např. k demokratizaci, prodlužování volného času a $v$ návaznosti na to se začal stále intenzivněji rozvíjet cestovní ruch. Zejména $v$ druhé polovině 20. století, tedy již v éře postindustriální, docházelo k zakládání cílených turistických atraktivit v podobě například nejrůznějších tematických parků. Starší zoologické zahrady byly inspirací. Ony samy byly v přivalu konkurence nuceny měnit svou tváŕ, rozvíjet priority a poslání. Staly se pevnou sou- 
částí nejen trávení volného času místních, ale též turistů a návštěvníků. Staly se jedněmi z nejnavštěvovanějších turistických a volnočasových atraktivit vůbec (Baratay \& Hardouin-Fugier, 2004), a mají tak velký vzdělávací potenciál.

Podoba (a historie) konceptů zoo vychází z obecnějších transformací paradigmat nahlížení společnosti na př́rodu (Hyson, 2000). Tento vývoj je jedním z př́kladů historie zastavěného prostoru, který zprostředkovává a reflektuje vztah člověka s př́rodou, a to doslovně i symbolicky (Borgards, 2016). Zoo slouží různým cílưm a prostředkům a jejich podoba je závislá na společenském, ekonomickém, kulturním, politickém či vědeckém kontextu - na diskurzech doby, které se mění (Mizicko \& Bell, 2001; Steinkrüger, 2013; obr. 1). Vysvětlení změn konceptu zoo je proto naprosto zásadní pro pochopení dynamicky se vyvíjejícího současného stavu vztahu člověka a zviřat, který se odráží i v ochraně životního prostředí a environmentálním vzdělávání. Tento článek proto diskutuje otázky: Jakým způsobem se měnil a utvářel koncept veřejnosti př́stupných zoo? Jak odráží vývoj vztahu člověka a př́rody? Jak Ize charakterizovat (evropskou) zoo současnosti a co z toho vyplývá pro environmentální vzdělávání?

Stěžejní otázkou zůstává, zda v evropské společnosti došlo ve vztahu se zviŕaty k odklonu od antropocentrismu k eko/biocentrismu, či nikoliv. Probyn-Rapsey (2018) se výslovně ptá, zda jde o fundamentální posun, či jen pokračování původního $v$ jiné formě. Zoo podle některých autorů právě přecházejí od antropocentrického $\mathrm{k}$ biocentrickému až k ekocentrickému pojetí s holistickým představováním biotopů. Tradiční vznik a podoba zoo je však spojen s antropocentrismem.

Obr. 1: Hlavní faktory ovlivňující podobu zoo

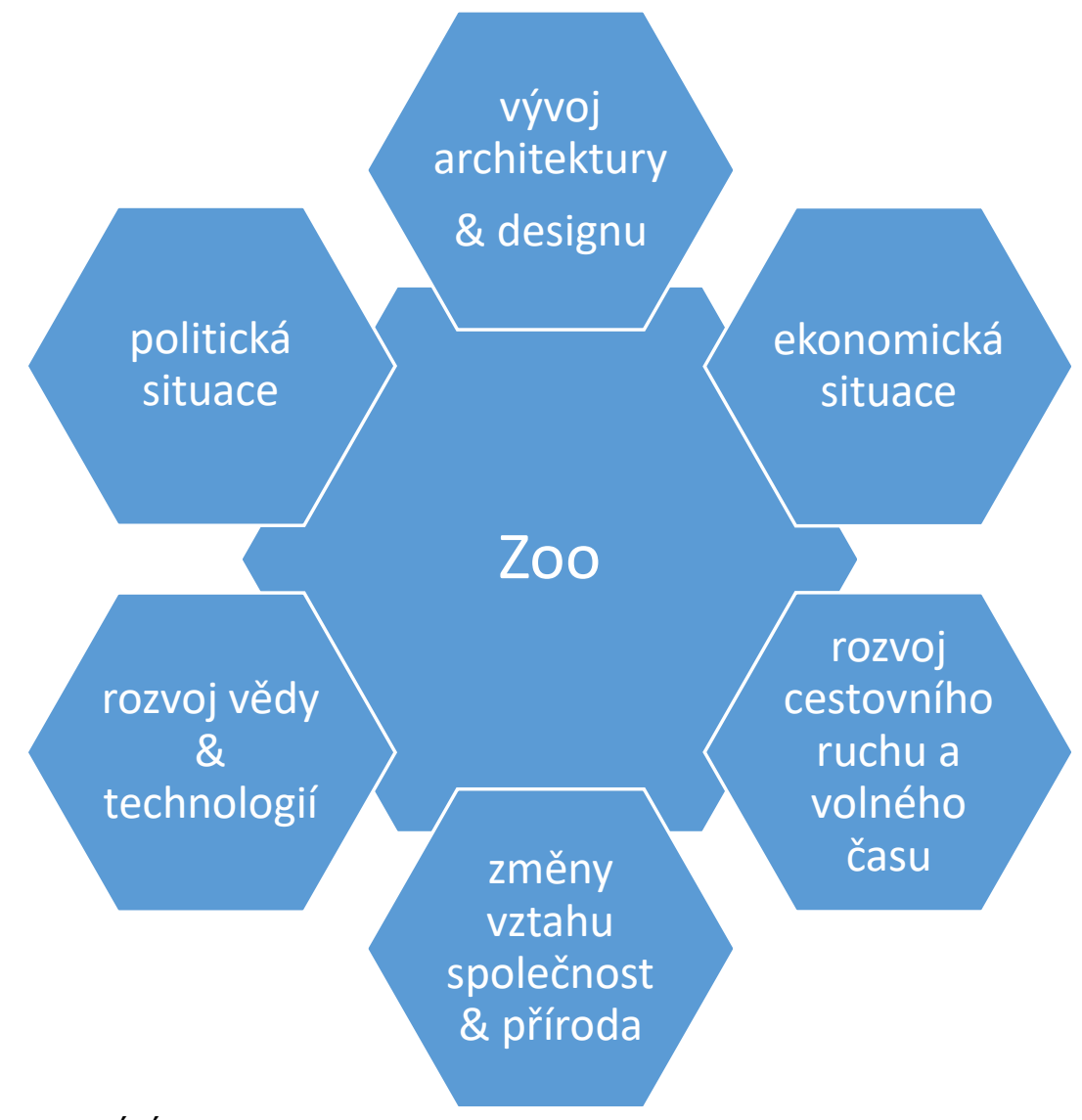

Zdroj: vlastní zpracování 


\section{Rešerše literatury}

Pro pochopení proměn konceptů zoo, a tedy i podoby současných zoo, je stěžejní provedení rešerše dosavadní odborné literatury. Vývoj zoo byl podrobně prvně zpracován v roce 1912 Loiselem, ovšem jeho text zůstal až do 21. století jen ve francouzštině (Meuser, 2019). Tato publikace je již více než sto let stará a od té doby došlo $\mathrm{k}$ mnoha paradigmatickým posunům. Historii zoo se odborné publikace soustavněji věnují teprve $v$ posledních třech dekádách. Dokládá to přehled více či méně významných publikačních príspěvků na toto téma. V roce 1994 vznikla publikace Zoo Book: The Evolution of Wildlife Conservation Centers od Lindy Koebner (1994). Téhož roku Rabb představil schéma evoluce zoo, které bylo později aktualizováno (Rabb, 2004; Gipps, 2014). Roku 1996 byla vydána kniha New worlds, new animals: from menagerie to zoological park in the nineteenth century (Hoage \& Deiss, 1996), která podrobně zachytila proměny konceptu zoo v průběhu 19. století. Přelomovou knihou o celém vývoji se stala publikace Zoo and Aquarium history: ancient animal collections to zoological gardens (Kisling, 2001), jak ostatně zmiňuje např. Meuser (2019). Velký encyklopedický přehled včetně informací o různých typech zoo a jejich vývoji přinesli Mizicko \& Bell (2001). Kritický náhled na jednotlivé vývojové koncepty zoo zajistila publikace $A$ different nature od Hancockse (2001). Následovala kniha ZOO: a history of zoological gardens in the West (Baratay \& HardouinFugier, 2004), která prezentuje zejména základní nejčastěji předváděnou linku evoluce zoo - tedy pojednává o vedoucích zoologických zahradách na Západě ( $v$ západní Evropě a Severní Americe). Ovšem zoo jsou lokalizovány i jinde a mají mnohem širší spektrum podob než jen vedoucí zoologické zahrady, jak zdůrazňuje např. Nekolný a Fialová (2018). Z hlediska proměn zoo (nejen) ve vztahu s vývojem architektury výrazně přispěla Meuser (2019).

Statě a kapitoly $\mathrm{k}$ tématu se objevují stále častěji, nebot́ obecně téma člověka a zviŕrete je více reflektováno $v$ rozsáhlých odborných publikacích (např. Borgards, 2016; Dittrich, 2000, Dollinger, 2012; Kalof, 2007; Kean \& Howell, 2018; Lindholm, 2013; May, 2020; Rees, 2011; Steinecke, 2009; Steinkrüger, 2013). Základní pohledy na problematiku jsou často obdobné, ale jednotliví autoři přidávají nová hlediska patřící $k$ jejich profesi, postoji a náhledu. Ve stručnější variantě se Ize s tématem setkat ve vědeckých článcích (např. Rabb, 2004; Parker, 2020) i kvalifikačních pracích (např. Goronzy, 2003). Kapitoly o vývoji zoo nalezneme rovněž již delší dobu v průvodcích o zoo (např. Lemke, 1987; Dobroruka a kol., 1989). Právě tyto průřezové publikace mohou mít význam jako zdrojový materiál pro geograficky zaměřený výzkum vývoje zoologických zahrad.

Řada zmíněných odborných publikací se věnuje poměrně podrobně i obdobím před vznikem vlastních zoologických zahrad (např. Kisling, 2001). Tento článek však cílí na vysvětlení změn až právě od 18. století tak, aby mohla lépe postihnout mechanismy, které nastaly $v$ době budování zoologických zahrad, a vyhnul se častým zestručněním a zkratkám, které mohou ovlivnit interpretaci současného stavu. Jeho podobě zatím nebylo ve výzkumných pracích věnováno príliš prostoru. Navíc jde o stále živé téma, které je vhodné průběžně aktualizovat. $V$ české literatuře jeho odborná reflexe dosud prakticky chyběla.

\section{Vývoj zoo}

\section{Vytváření konceptu moderní zoo}

Do 18. století měla zařízení se živými zviřaty podobu tzv. menažerie (menagerie), což vychází z francouzského slova "ménage", tedy domácnost, v tomto smyslu královská domácnost. Vládnoucí vrstvy byly totiž těmi, které menažerie zakládaly a navštěvovaly. Menažerie byly určené pro zábavu jako živá sbírka kuriozit (Mizicko \& Bell, 2001). Jednalo se o exkluzivní záležitost, která dokazovala moc a sílu skrze chovaná zviŕata (Hoage \& Deiss, 1996). Menažerie Ludvíka XIV. ve Versailles z 60. let 17. století byla vybudována v podobě centrální stavby - pavilonu pro císaře, který symbolizuje pána světa v centru - a navazujících výběhů okolo. Toto pojetí se značnou symbolickou hodnotou se stalo předobrazem pro další menažerie na následujících sto let (Dittrich, 2000). Menažerie odrážely antropocentrický způsob myšlení. 
Za nejstarší zoologickou zahradu současného světa bývá označována zoo ve Vídni, v zámeckém areálu Schönbrunn - Tiergarten Schönbrunn (Kisling 2001), založená 1752. Toto prvenství však bývá leckdy nesprávně interpretováno. Šlo o menažerii, která byla zpřístupněna (navíc až později), nikoliv o přelomovou zoologickou zahradu s novými funkcemi. Názory na její pojetí se i přesto liší. Steinkrüger (2013) tvrdí, že po vzoru Versailles postavený komplex stále symbolizoval absolutistickou moc habsbursko-lotrinské dynastie a oddělení př́rody a kultury. Navíc ve stejné době vznikaly po vzoru Francie i jiné královské menažerie - $v$ jednotlivých německých státech např. $v$ mnichovském Nymphenburgu $v$ tehdejším Bavorském království (Steinecke, 2009). Oproti tomu Dittrich (2000) předkládá myšlenku, že architektonický koncept je sice obdobný jako ve Versailles, avšak vychází z jiného intelektuálního pojetí - již více osvícenského. Každopádně jde o areál zahrnující poslední existující prvky královské menažerie, navíc ještě s původními barokními stavbami, který se časem proměnil v moderní zoologickou zahradu.

Zoologická zahrada moderního pojetí je však až výsledkem Velké francouzské revoluce (Dittrich, 2000; Parker, 2020). V roce 1793 vyšel ve Francii dekret o zákazu pouličního vystavování zviŕrat a převezení takovýchto jedinců do pařížské botanické zahrady. Zviŕrecí show tímto zanikly a jejich provozovatelé se leckdy stali zaměstnanci nově vzniklé instituce (Lindholm, 2013). První moderní - vědeckou - zoologickou zahradou tedy byla pařížská Menagerie du Jardin des Plantes, zpřístupněná 1793, pobočka nově vzniklého národního muzea př́rodní historie, kam se zároveň přesunula zviřata z královské menažerie ve Versailles (Dittrich, 2000; Lindholm, 2013). Novinkou této demokratické instituce nebyl jen proces vzniku, ale též jiná architektonická podoba. Místo dosavadních panoptických principů s jedním centrálním bodem byly využity romantické pitoreskní stavby a více úhlů pohledu do různě tvarovaných výběhů (Parker, 2020).

Prvním areálem s využitím názvu "zoologická zahrada" se stala London Zoo, zpřístupněná $v$ roce 1828 (Borgards, 2016; Dittrich, 2000). Také ta byla symbolem moci, což dokazuje i fakt, že jedním z jejích zakladatelů byl někdejší guvernér Indonésie Thomas Stamforf Raffles (Borgards, 2016). Zároveň se do ní v roce 1831 přesunula značná část kolekce zviřat menažerie v londýnském Toweru, která měla tradici již od roku 1235, kdy byla založena Jindřichem III. (Lindholm, 2013).

\section{Zoo 19. století}

V 19. století v Evropě probíhalo mnoho procesů, které zásadním způsobem ovlivnily podobu té doby. Klíčovými byly demokratizace a industrializace (Steinecke, 2009) s potřebou koncentrace lidí, čímž docházelo $\mathrm{k}$ urbanizaci - $\mathrm{k}$ rozvoji měst. Prostor města byl doménou lidí odtrženou od přírody, a proto se již od počátku začala budovat také městská zeleň - „zelené oázy měst". Ty nelze vnímat jako něco, co by stálo v protikladu města, ale naopak jako jeho jasnou součást, ostatně známou již ze starověku. Zahrady a parky včetně zoo byly vedle divadel, novin, galerií, muzeí či knihoven jedněmi z městských institucí (Frost, 2011; Grazian, 2017; Van Reybrouck, 2005). Zoo byly zároveň heterotopií $\mathrm{k}$ všednímu dni ve městě a stále jedním ze symbolů moci, resp. národní a městské prestiže. Od poloviny 19. století se hlavní a přistavní města bez zoologické zahrady stávala méně významnými (Steinkrüger, 2013). Zoo antropocentricky působily jako symbol lidské kontroly nad př́rodou, a zároveň jako symbol kontroly nad kolonizovaným světem lidí v Africe, Asii či Americe. Zvířata sloužila podobně jako např. koření jako diplomatická měna (Kean \& Howell, 2018).

19. století bývá označováno jako první fáze zakládání moderních zoologických zahrad. Bývá však opomíjeno několik paralelních procesů, $\mathrm{k}$ nimž během této doby také docházelo. $V 19$. století stále existovaly královské menažerie, které byly určené jen pro elitu. Z některých královských menažerií se nicméně postupně staly národní zoo (Kean \& Howell, 2018). To souviselo s posunem politického uspořádání zemí od monarchistických k parlamentním systémům. Existovala i zařízení založená na obchodu se zvířaty, která se proměnila $v$ zoo. S př́chodem občanské společnosti, kapitalismu a soukromého vlastnictví vznikaly zejména $v 1$. polovině 19 . století také privátní pojízdné menažerie - typické pro Nizozemsko či Anglii (Steinkrüger, 2013). Zprostředkovávaly informace o zviŕatech a někdy byly i poměrně seriózně vzdělávací. Později se ale staly společensky neakceptovatelnými kvůli nevhodným podmínkám pro zviŕata. Šlo vlastně o předchůdce raných zoologických zahrad a po určitou dobu byly dokonce jejich konkurenty (Dittrich, 2000). 
Čím se tedy $v$ 19. století nově vznikající zoologické zahrady lišily od někdejších menažerií (a z velké části i od pojízdných menažerií)? Macho (2005) tvrdí, že se odlišovaly ve čtyřech bodech: 1) přístupnost pro širokou veřejnost (ta již byla u pojízdných menažerií), 2) spojení s vědou (taxonomie, Darwinova teorie), 3) spojení s národní prestiží, resp. symbolickým ztělesněním př́slušné komunity, 4) asociace $s$ idealizovanou př́rodou ( $v$ podobě parku). Ovšem i př́roda se v idealizované podobě anglického parku nacházela jen $v$ části pro návštěvníky, nikoliv $v$ expozicích zviŕat, a zpřístupnění pro veřejnost bylo zpočátku značně omezené (Steinkrüger, 2013). Zoo se masovou (turistickou) atraktivitou staly teprve až na počátku 20. století (Beardworth \& Bryman, 2001).

Svět 19. století působil nevyčerpatelně a pokračovala lidská snaha a touha věnovat se sběru přírodnin. Proto se i v zoologických zahradách objevovaly rozsáhlé kolekce zvírat $v$ duchu sběratelství. Tomu pomohl tehdejší rozvoj taxonomie druhů (např. Linné), protože dosavadní sbírky byly neutříděné ( $v$ menažeriích pouze prezentace něčeho kuriózního). Zoo byly nově členěny podle vědecké klasifikace zviŕat a staly se taxonomickými živými muzei (Lindholm, 2013; Ullmann, 2019). Bylo nutné vystavovat co nejvyšší počet taxonů (důraz na kvantitu a odlišnost, jinakost, velké expozice by zbytečně zabíraly místo jiným druhům). Tehdejší zoo více dbaly na zoologický obsah než na prostor daného místa a prostředí (Kalof, 2007), např. expozice šelem se v zásadě nelišily od těch $\checkmark$ menažeriích.

Klasifikační dělení Ize vidět nejen ve smyslu rozvoje vědy a šíře poznání, ale také jako separaci přirozených vztahů a interakcí. Jednotlivé druhy byly v samostatných ubikacích, šlo tak o vytvoření "cel" a zároveň jevišt', v nichž jsou herci odděleni. To zaručovalo skvělou viditelnost, kterou dodnes aplikují tematické parky. Parker (2020) podotýká, že výzkum v zoo 19. století je spojen s neúspěchy. Odchovávat zvírata nebylo běžné, navíc žila $v$ podmínkách, které nenapodobovaly jejich přirozené prostředí, a tak ani nešlo pozorovat jejich přirozené chování. Výzkum mohl být vzhledem k vysoké úmrtnosti zaměřen na komparativní anatomii (Woods, 2018).

\section{Etapizace vývoje zoo}

Na konci 19. století již bylo zřejmé, že zoo mají být institucemi zajištujícími vzdělání, výzkum a rovněž ochranu přírody. Původní "taxonomický a klecový" myšlenkový přístup byl vážněji (byt́ $z$ dnešního pohledu jen částečně) nabourán Carlem Hagenbeckem na přelomu 19. a 20. století (Hancocks, 2001). Ačkoliv se vývojové pojetí jednotlivých autorů (např. Poley, 1993; Rabb, 1994; Axelsson \& May, 2008; Steinecke, 2009; Hosey, Melfi, \& Pankhurst, 2013) liší, shodují se na významu změn započatých právě Hagenbeckem - obchodníkem se zvířaty a zakladatelem zoologické zahrady (nazvané později Tierpark) umístěné ve Stellingenu u Hamburku. Nově zde totiž šlo o koncept založený na vytváření krajiny napodobující místa výskytu zviŕat v podobě tzv. panoramat (či dioramat) a nahrazení taxonomického expozičního přístupu tím geografickým či biotopovým (Axelsson \& May, 2008). Jednalo se o první reálnou inspiraci prírodou v prostředí zoo (Kleiman, Thompson \& Baer, 2010). Novinkou bylo vytváření iluzí (Holtorf, 2008), kde vnímaná volnost šla ruku v ruce s tehdejšími společenskými ideály volnosti. Na druhou stranu, ačkoliv došlo ke vzniku iluze svobody, náhled na zviŕata se změnil méně než fyzické pojetí expozic (Kalof, 2007).

V dalších desetiletích následovala stagnace, zoo byly oprávněně kritizovány (Durrell, 2001), a potřebovaly se proměnit. Až později ve 20. století nebyla transformace pouze fyzická, ale také filozofická, paradigmatická (Hyson, 2000). Druhá radikální změna ve vývoji zoo přišla více než půl století po Hagenbeckovi s vytvořením konceptu imerzních expozic v 70. letech 20. století v USA (Kleiman, Thompson \& Baer, 2010; Ullmann, 2019). Přístup vychází z přirozeného prostředí typického pro chované zviře, kde návštěvník minimálně opticky vstupuje (je vnořen) do stejného prostředí (habitatu) se zviřaty a rostlinami. To bylo umožněno díky novým materiálům a technologiím (Meuser, 2019). Tento design by měl mít jasnou normu a filozofii (Hancocks, 2001).

Zoo začaly být více přírodního/naturalistického charakteru, plnit potřeby zviŕat (Kleiman, Thompson \& Baer, 2010) a také funkci ochrany př́rody, čímž se zvýšil význam vzdělávání. To pomohlo vymanit se z negativních konotací a stát se více atraktivními jako turistické destinace. Poley (1993) trefně podotýká, že vývoj zoo je vlastně proměnou od bohatých sbírek zviŕat a zábavy k přitažlivým 
místům, kde se člověk opravdu může setkat $s$ prírodou. Převažuje tedy evoluční náhled, $v$ němž se jedná o posun od antropocentrismu k ekocentrismu, od taxonomického pojetí k environmentálnímu se zvyšujícím se důrazem na zábavné vzdělávání vedoucí $k$ ochraně přírody - k ochranářskému edutainmentu (obr. 2).

Obr. 1: Evoluční náhled na vývoj nejprogresivnějších zoo

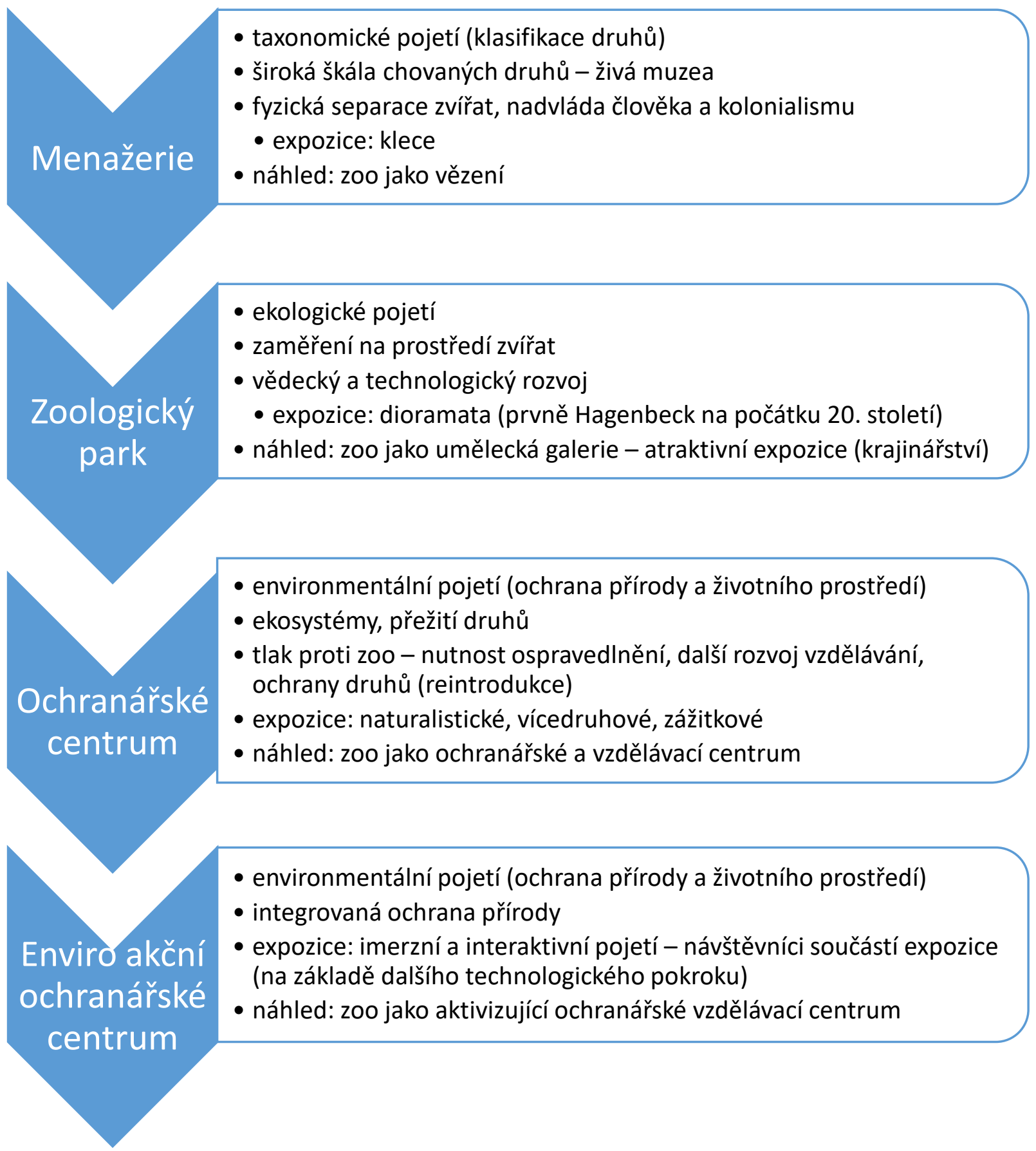

Zdroj: vlastní zpracování na základě Gipps (2014), Rabb (2004), Mizicko \& Bell (2001)

Meuser (2019) se na vývoj dívá více z architektonického hlediska a rozlišuje celkem šest fází vývoje (tab. 1). Zatímco na úplném počátku stavby $v$ zoo vycházely $z$ tradic krajinářských parků (např. Schönbrunn), později se zoo architektura vyvinula $v$ samostatnou kategorii. Podoba jednotlivých fází vychází ze tří odlišných náhledů (politiky, zoologie a designu), přičemž v každé fázi se mění 
význam reflexe těchto náhledů. Zatímco exotické stavby odkazující na oblast původu zvířat reflektovaly politické aspekty $v$ podobě kolonialismu, snaha o expozice bez mřízí vycházela z př́istupů zoologických. Změna dưrazu na design byla patrná u přechodu na funkční i experimentální stavby moderny a funkcionalismu. Do 60. let 20. století se i v nejvyspělejších zoo stavěly klece multi-účelové povahy, které se daly využít pro jakýkoliv taxon (Van Vliet, 2015) a které nezohledňovaly prostředí, resp. podmínky, $v$ nichž zviře přirozeně žije (Durrell, 2001). Čtvrtá fáze $v$ rámci snahy návratu $k$ př́irodě pracovala zejména se zoologickými a politickými aspekty, zatímco velké spektakulární (často tematické) budovy posledních tří dekád kombinují design a zoologickou podstatu (Meuser, 2019). Ullmann (2019) zastává mírně jiný náhled, když uvádí, že vývoj z architektonického hlediska byl svázán s dobovou architekturou zejména zpočátku - např. romantismus. Pozdější spojení s funkcionalismem, konstruktivismem či brutalismem byly výjimkami a postmodernismus a dekonstruktivismus již v architektuře zoo zastoupen není.

Tab. 1: Vývojové proměny architektury zoo dle N. Meuser

\begin{tabular}{|c|c|c|c|}
\hline Fáze & Charakteristika & Reflexe & Období \\
\hline $\begin{array}{l}\text { Zahradní a krajinářská } \\
\text { architektura }\end{array}$ & $\begin{array}{l}\text { Romantizující stavby (např. pavilony) kraji- } \\
\text { nářského parku }\end{array}$ & - & Do 1800 \\
\hline $\begin{array}{l}\text { 1. generace zooarchi- } \\
\text { tektury }\end{array}$ & $\begin{array}{l}\text { Koloniální styl - připomínky oblasti původu } \\
\text { zviŕatat }\end{array}$ & politická & $\begin{array}{l}1800- \\
1900\end{array}$ \\
\hline $\begin{array}{l}\text { 2. generace zooarchi- } \\
\text { tektury }\end{array}$ & $\begin{array}{l}\text { Krajinné panorama - príkopy, nahrazení } \\
\text { mříží }\end{array}$ & zoologická & $\begin{array}{l}1900- \\
1930\end{array}$ \\
\hline $\begin{array}{l}\text { 3. generace zooarchi- } \\
\text { tektury }\end{array}$ & $\begin{array}{l}\text { Formalismus a funkcionalismus - technolo- } \\
\text { gie a funkčnost }\end{array}$ & designová & $\begin{array}{l}1930- \\
1960\end{array}$ \\
\hline $\begin{array}{l}\text { 4. generace zooarchi- } \\
\text { tektury }\end{array}$ & $\begin{array}{l}\text { Stavby inspirované krajinou - dle potřeb } \\
\text { zviŕat }\end{array}$ & $\begin{array}{l}\text { politická \& zo- } \\
\text { ologická }\end{array}$ & $\begin{array}{l}1960- \\
1990\end{array}$ \\
\hline $\begin{array}{l}\text { 5. generace zooarchi- } \\
\text { tektury }\end{array}$ & $\begin{array}{l}\text { Rozvoj značky a ikonografických budov - } \\
\text { zážitkovost, dobrodružnost, tematičnost }\end{array}$ & $\begin{array}{ll}\text { designová } & \& \\
\text { zoologická } & \end{array}$ & Od 1990 \\
\hline
\end{tabular}

Zdroj: vlastní zpracování na základě Meuser (2019)

May (2020) tvrdí, že historie zoo je vyprávěna dvěma způsoby. Většina autorů ji představuje jako pozitivní vývoj - jasnou evoluci od antických sbírek přes menažerie k zoologickým zahradám s vzděláváním a výzkumem. Druhý proud naopak zastupuje kritický postoj tvrdící, že žádný reálný vývoj zoo neexistuje a zoo jsou jen zbytkem koloniálního světa a myšlení 19. století. Ekonomické a politické důvody a symbolika potlačování prírody a vyzdvihování moci člověka je stále stejná, jen se schovala za profesionální prístup (May, 2020). Skutečností je, že se zvírata v zoo od poloviny 20. století dožívají výrazně vyššího věku než dřive, zvětšují se znalosti o vhodných podmínkách pro chov a odchov zviŕat, což je dokladováno vysokým počtem odchovů včetně vzácných taxonů, a roste i důraz na ochranu přírody a vzdělávání. Existuje větší vzájemná kooperace a koordinace mezi jednotlivými zoo (Nekolný, 2021). Největším omezením většiny vývojových náhledů je však fakt, že zachycují vývoj na základě změn jen ve vědecky ř́zených zoologických zahradách. Reálně dochází ke stále se zvětšující diverzifikaci zoo a jejich úrovně po celém světě, což bývá často v literatuře opomíjeno (Nekolný \& Fialová, 2018). Již Coe (1986) zdůrazňoval, že vývoj zoo není liniový (evoluční), jak znázorňuje obr. 2, ale naopak probíhal a probíhá v několika rovinách, z nichž se štěpí a následně současně koexistuje mnoho typů zoo - tzv. koevoluce. 


\section{Zoo současnosti}

Jaká je tedy zoo současnosti? Autoři prezentující evoluční rozvoj zoo vnímají ty současné jako ochranářská centra (např. Gipps, 2014; Rabb, 2004). Zoo nemají být jen sbírkou zvířat, ale také nástrojem k ochraně prírody a biotopů (Kelly, 1997). Zoo mají klíčovou roli v intepretaci prírody a ve vzdělávání směřujícím $\mathrm{k}$ její ochraně (Catibog-Sinha, 2008). V praxi nicméně existují nejen opravdu moderní instituce zobrazující vztahy $\vee$ prírodě, ale také zařízení, která spíše připomínají zvěřince předchozích staletí. Fenomén současných zoo 21 . století je komplexní; asi nejlépe složitost tohoto systému dokladuje široká typologie zoologických expozičních zařízení (zoo) na různých kvalitativních a hierarchických úrovních (Nekolný \& Fialová, 2018).

V současných zoo se navíc projevují zejména dva (do jisté míry) protichůdné, ale zároveň návštěvnicky atraktivní (zážitkové) trendy. Prvním je snaha představovat plnohodnotné habitaty, kde $v$ napodobenině přirozeného prostředí spolu žijí přirozeně početné skupiny někdy $i$ více druhů zviřat, které vzájemně interagují. Klíčovým principem se ukazuje imerze, tedy vnoření návštěvníka do prostředí, v němž žijí zviŕrata a rostou rostliny. Jde o typický ekocentrický princip, díky němuž má návštěvník možnost pochopit, $v$ jakém prostředí zvíře žije. Zejména by $v$ návštěvníkovi měly zůstávat pocity a "obrazy" z návštěvy (Van Vliet, 2015), které mohou být důležitou součástí vzdělávacího procesu v prostředí zoo. Interaktivní zážitky jsou pro učení vždy lepší a silnější než ty pasivní. Navíc výzkumy ukazují, že lidé ve více přírodním prostředí vydrží delší dobu a rovněž zvírata chovaná $\checkmark$ takových podmínkách jsou vnímána lépe (Kleiman, Thompson \& Baer, 2010). Prostředí s prírodními materiály a živými stromy umožňuje chovaným zvíratům více projevit jejich přirozené schopnosti a dovednosti. Zviŕata jsou aktivnější, a tedy atraktivnější. Veřejnost tak má možnost se zároveň dozvědět více o jejich přirozeném chování.

Fyzické prostředí má přímý vliv na postoje lidí. Studie odkazují na silnější pro-ochranářské aktivity návštěvníků díky naturalistickému prostředí. Inklinují k tomu více lidé, kteří zoo navštěvují opakovaně (Godinez \& Fernandez, 2019). Dále je možné aktivizovat návštěvníky např. pomocí speciálních akcí (Kleiman, Thompson \& Baer, 2010). Jako cenné př́klady imerzních vzdělávacích expozic jsou uváděny průchozí motýlí haly s atraktivními pestrobarevnými živočichy a vysvětlením vztahů mezi nimi a rostlinami (Catibog-Sinha, 2008). Lidé jsou aktivizováni informačním systémem i praktickými ukázkami toho, jak sami mohou pomoci, zejména lokální fauně a prírodě obecně. Zejména $\checkmark$ posledních letech je kladen dưraz na tř́dění odpadu, podporu místní biodiverzity pomocí hmyzích hotelů či "motýlích luk" (Nekolný, 2020). K tomu navíc nejsou potřeba žádné velké investice a takový přistup je reálný pro široké spektrum zařízení.

Ani po půl století však imerze není jediným či převažujícím aktuálně využívaným přístupem, a to už z podstaty vysoké finanční nákladnosti. Stále existují staré mnohdy nevyhovující expozice odkazující na prístupy 19. století (Kleiman, Thompson \& Baer, 2010) a vznikají nové stavby odpovídající spíše starším vývojovým etapám. Málokterá zoo tak reflektuje jen "nejnovější fázi" vývoje. Zoo mají eklektickou povahu (Mizicko \& Bell, 2001; Rees, 2011) - zrcadlí v sobě svůj vývoj, tedy mj. expozice z různých období reprezentující odlišné vizuální, tematické či morální hodnoty a přístupy. To na druhou stranu zajištúuje návštěvnicky pestřejší zážitky. Na př́kladu srovnání existujících expozic Ivů Ize zachytit obrovské rozdíly v prostorovém, expozičním i konceptuálním pojetí - mřǐže, brutalistní betonová architektura vs. rozsáhlé imerzní naturalistické výběhy (obr. 4).

Meuser (2019) stanovila tři typy staveb podle jejich účelu vycházející z jiných sociálních konstruktů (tab. 2). Všechny typy existují v současných zoo jako výsledek vývoje a vyjadřují zmíněný eklekticismus. První stavby $v$ zoo vycházely z potřeby separace člověka a zvírete - metaforou je zde "vězení". Architektonicky je v tomto pojetí řešena otázka hranic, zatímco dnes převládající snahou je viditelnost hranic minimalizovat (viz imerze). $\mathrm{K}$ tomu je potřeba práce s perspektivou a divadelní náhled jeviště a hlediště. Počátky tohoto př́stupu jsou spojeny s 60 . lety 20 . století a rozvojem environmentálních přístupů a behaviorální biologie. Třetí typ vychází z klasického pojetí muzea. Jde o předávání znalostí a o rostoucí snahu vzdělávat. Integrace muzeálních prvků je jedním ze současných zoo trendů (Meuser, 2019). 
Tab. 1: Typologie zoostaveb podle jejich účelu na základě jiných sociálních konstruktů

\begin{tabular}{|l|l|l|}
\hline $\begin{array}{c}\text { Typ stavby dle účelu } \\
\text { - vyjádřeno metafo- } \\
\text { ricky }\end{array}$ & \multicolumn{1}{|c|}{ Charakteristika } & $\begin{array}{c}\text { Př́klad současné stavby } \\
\text { (rok dokončení) }\end{array}$ \\
\hline vězení & $\begin{array}{l}\text { bezpečnostní a prostorové limitace, } \\
\text { separace, "estetika omezení" }\end{array}$ & pavilon slonů, Erfurt (2015) \\
\hline divadlo & $\begin{array}{l}\text { prezentace jeviště vs. hlediště, "es- } \\
\text { tetika perspektivy" }\end{array}$ & pavilon slonů, Köln (2004) \\
\hline muzeum & snaha vzdělávat, "estetika znalostí" & pavilon slonů, Mnichov (2016) \\
\hline
\end{tabular}

Zdroj: vlastní zpracování na základě Meuser (2019)

Z výše zmíněného je zřejmé, že zviřata nejsou vystavena v zoo sama. Doplňuje je soustava prvků, která má zarámovat kontext a evokovat určité dojmy a prostředí. Nejvyvinutější podoba zoo - biopark - je založena na ekocentrickém (holistickém) přístupu s cílem představit život ve vší komplexnosti; využívá principů a znalostí z různých typů expozičních zařízení, nejen zoo. Jde o odstranění "chybné separace" jednotlivých částí př́rody, např. živočichů a rostlin (Hoage \& Deiss, 1996). Někdy to platí nejen o prvcích prírodních, ale i kulturních (etnografických). Proces etnografizace navázal na prístupy Hagenbecka z počátku 20. století, když se objevil v amerických zoo a tematických parcích, a mohl tak rozšiŕit koncept imerzní expozice. $V$ Evropě se zájem o toto pojetí zvýšil po vybudování puebla v pouštní hale v Arnhemu (NL) roku 1994 (Kleiman, Thompson \& Baer, 2010). Má jít jen o ilustrace, které nemají odvádět pozornost od chovaných živočichů (Ullmann, 2019). Je tomu však skutečně tak?

$\checkmark$ rámci tematických areálů jsou návštěvníci vtaženi do prostředí, která jsou plná klišé. Návštěva takových zoo se nově často stává cestou kolem světa (Meuser, 2019). Rozdělení zoo podle kontinentů nemá podle Van Vlieta (2015) velkou vzdělávací hodnotu, pokud není zároveň zaměřeno na biotopy. Součástí geograficky pojatých zoo se často stávají etnografické prvky. Např́klad $v$ americké Woodland Park Zoo v Seattlu s prvními imerzními expozicemi vůbec doplnily africkou savanu ze 70. let chýše africké vesnice (ale až v roce 2001). Jedná se o rozšíření původního konceptu krajinné imerze o "kulturní rezonanci" $s$ cílem představit závislost na planetě Zemi. Tento prístup vede skrz prezentaci lidové architektury, která souzní s prírodním prostředím a představuje etnika jako významný prvek $v$ udržitelném rozvoji míst $\mathrm{s}$ volně žijícími živočichy. Stavby reflektují realitu a původní využití staveb je vysvětleno (interpretováno) informačním systémem, stejně jako naučné tabule o ochranářských projektech zoo ve východní Africe. Takovýto komplexní vzdělávací přistup může být velmi hodnotný. Nedostatečná interpretace naopak zvyšuje riziko, že bude docházet $\mathrm{k}$ velkým generalizacím a prohlubování stereotypů (Osayimwese, 2016). Navíc zoo potřebují myslet na atraktivitu, a tak často rezignují na témata, která jsou známá a zajímavá jen pro část lidí (Van Vliet, 2015). Pojmenování expozičního celku podle přirodního chráněného území (např. národního parku) umožňuje návštěvníky geograficky vzdělávat a zároveň propojit činnosti vzdělávání a ochranu přírody ex situ ( $\vee$ zoo) $\mathrm{s}$ in situ ochranářským projektem, který zoo podporuje $v$ místě přirozeného výskytu. Typickým př́kladem komplexní expozice je tropická hala Masoala v Zoo Zürich (CH), odkazující na národní park na Madagaskaru. Takové pojetí při dostatečné interpretaci ukazuje relevanci tematického přístupu pro potřebu ochrany přírody. Vědecky řízené zoo totiž cílí (či by měly cílit) na propojování funkcí zoo do podoby ochranářského edutainmentu, tedy přístupu, v němž je návštěvník zábavnou formou vzděláván o udržitelnosti a ochraně př́rody a veden k nim (Carr \& Cohen, 2011; Patrick \& Tunnicliffe, 2013). 
Obr. 2: Aktuálně existující expozice Ivů v členských zoo EAZA ve Španělsku (Zoobotánico Jerez, Zoo Aquarium de Madrid, Zoo Barcelona), stav 2019

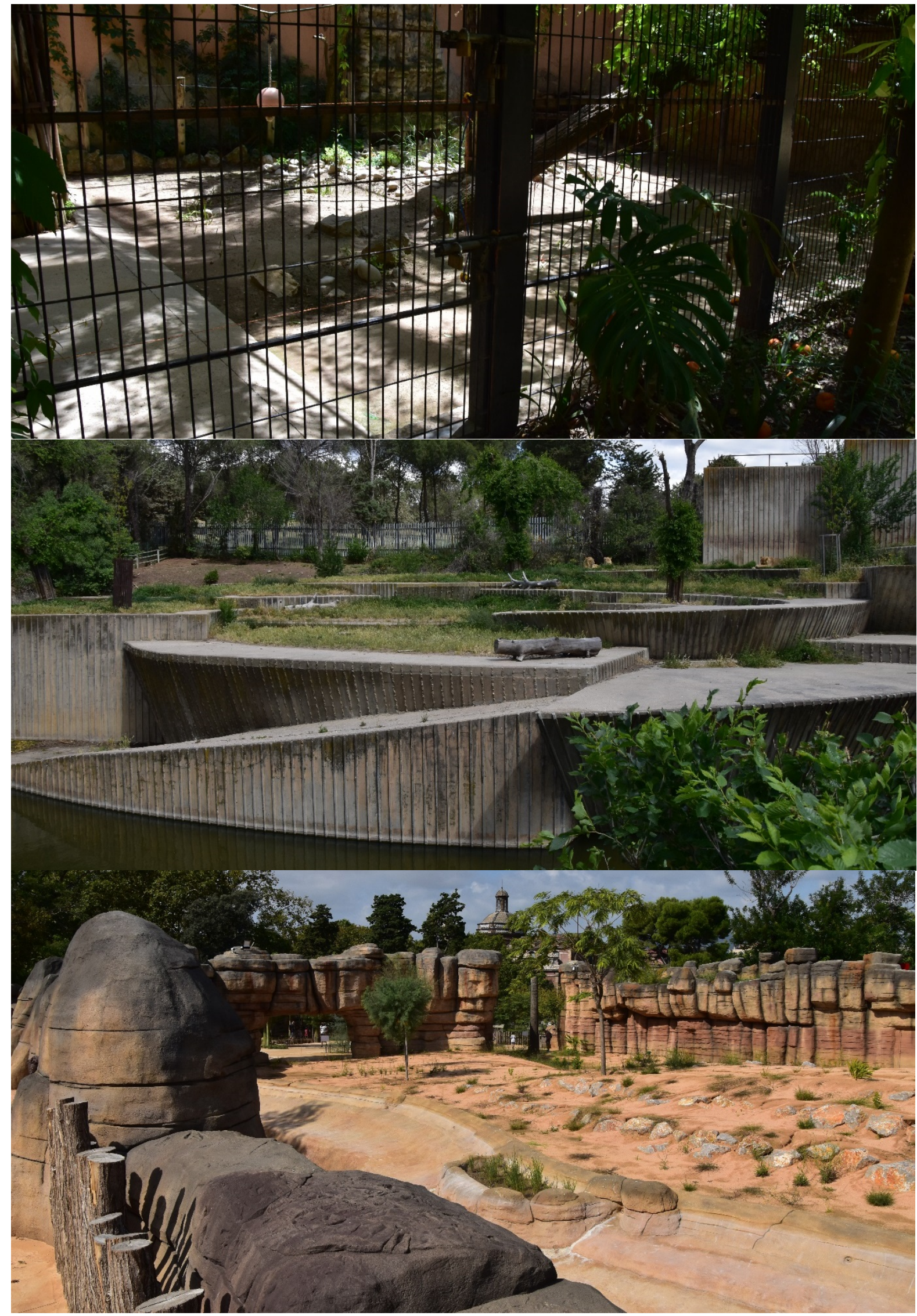

Zdroj: vlastní terénní šetření, 2019 
Zmíněné pojetí v kontextu tematizace a cílení na příběhy a zážitky vysvětlují př́ícinu, proč je v současných zoo tolik etnografických prvků. Jedním z vývojových proudů navazujících na tradiční zoologické zahrady jsou proto zážitkové zoo. Důraz je v nich kladen na návštěvnickou infrastrukturu. $\checkmark$ rámci zoo jsou tak podobně jako $v$ klasických tematických parcích $k$ dispozici komerční prvky obchody a občerstvení, často tematicky spojené s prezentovaným tématem. Vybrané téma je na druhou stranu cenným prostředkem pro vzdělávání (Van Vliet, 2015). Snahou je (mělo by být) zprostředkovat co nejširší zážitek ze světa zviŕă doplněný o vzdělávací přidanou hodnotu (Meuser, 2019). Vzdělávací aspekt je (měl by být) jedním z klíčových prvků při projektování nových expozic (Ross \& Gillespie, 2008). Využívána je i prezentace odstrašujících př́padů (např. suvenýry ze zvírat; Nekolný, 2020).

Zážitkově koncipované zoo vznikají zejména na základě předobrazu významných zoologických zahrad v USA a Nizozemsku. Celosvětovým průkopníkem se stal areál Animal Kingdom na Floridě. Do střední Evropy se pojetí rozširíilo na konci 20. století, když se první jasně tematickou zážitkovou zoo stala Zoo Hannover. Na počátku 90. let 20. století jí hrozilo uzavření, a tak se od roku 1996 začala transformovat fyzicky i symbolicky. Kromě zcela nového pojetí expozic ve stylu amerického tematického parku nese $v$ názvu označení zážitková - Erlebnis-Zoo. Navrátil se exotismus, a $v$ této zoo tak mj. vznikl indický palác pro slony či expozice medvědů ledních s bazénem u napodobeniny kanadského př́stavního města (Goronzy, 2003). Toto zážitkové propojení má jen málo společného s realitou, a proto vyvolává otázku autenticity. Důležité je zároveň zdůraznit, že zatímco krajina symbolismu $\vee$ zoo 19. století byla spojena $s$ tehdejším kolonialismem, současné etno-odkazy mají v postmoderní společnosti vyvolávat vzpomínky, asociace a nejrůznější př́iběhy. Meuser (2019) uvádí, že zážitkové zoo jsou vlastně v rozporu s prezentací zoo jako vědecké instituce, a ptá se, zda právě odborné zařízení kvůli marketingu a financím obětuje svou identitu. Výstavba takových tematických zážitkových areálů si navíc žádá velmi vysoké investice. Na druhou stranu výzkum provedený v roce 2000 v Erlebnis-Zoo Hannover potvrdil, že lidé do této zoo jezdí z větší vzdálenosti než v případě ostatních zoo. Zoo má nadregionální význam (Goronzy, 2003). V roce 2016 byla zpřístupněna nová vysoce tematizovaná zážitková Wildlands Adventure Zoo Emmen (NL), jejiž slabinou se ukázala absence postupného budování, tedy větších změn pro další roky, typických pro většinu zoo (rychlý pokles zájmu). Z výše zmíněného vyplývá význam rekreace, obnovy zábavy a potřeby inovací jako motivací k návštěvě a udržitelnosti konceptu.

Druhý zážitkový trend prímo souvisí se zviŕaty. Jedná se o možnost kontaktu s určitými zviŕaty (což částečně může umožňovat i imerzní pojetí - např. průchozí expozice) a také o personifikaci zvířat, respektive antropomorfní náhled, kdy jsou zviřatům přisuzovány lidské vlastnosti (Woods, 1998; Kean \& Howell, 2018). Např́klad jim jsou dávána lidská jména a jsou slaveny jejich narozeniny. To patří k historii zoo po celou dobu jejich existence, ale s nárůstem komercionalizace došlo ke zvýšenému (marketingovému) využití těchto praktik. Větší důraz na zážitky může být dlouhodobě rizikový proto, že by se zoo mohly dostat zpět do postavení institucí primárně pro lidi a pouze sekundárně pro zvírata (Frost, 2011). Na druhou stranu od oblékání šimpanzů do oblečků apod. se ve vyspělých zemích již před několika desetiletími upustilo a je dnes nemyslitelné. Ustupuje se od umělých odchovů a je vysvětlováno proč. Přes všechny proměny však návštěvnicky oblíbené druhy - zejm. savčí megafauna (např. sloni, žirafy, velké kočky, lidoopi) - zůstávají trvalou stěžejní součástí zoo (Kean \& Howell, 2018). Mohou být totiž motivací k návštěvě a potažmo zdrojem financí pro podporu ohrožených druhů. Vzdělávací "show" s ikonickými lachtany či delfíny, která obohacuje život zvírat, navíc může dobře posloužit pro prezentaci environmentálních rizik, např. znečištění vody a oceánů ( $\mathrm{Ne}-$ kolný, 2020). Některé zoo využívají část financí ze vstupného k podpoře ochranářských projektů in situ ( $v$ místě přirozeného výskytu), takže úroveň návštěvnosti dokonce prímo ovlivňuje aktivity na poli ochranářském. Zároveň zapojením návštěvníků do těchto činností vzdělává a upozorňuje na nutnost ochrany prírody.

Antropomorfní pojetí je sice $v$ rozporu s vnímáním zviřat jako součásti přírody, ale zároveň přitahuje pozornost a zájem, což může vést $k$ většímu porozumění (Woods, 1998). $V$ progresivních vědecky ř́zených zoo takový př́stup v posledních letech zeslabuje a význam druhu je dáván nad význam jedince. O to více atraktivní jednotlivce pojmenovávají a v marketingu využívají ostatní 
(často soukromé) zoo, které potřebují přilákat co nejvíce návštěvníků. Je nutné si uvědomit, že zoo jsou ekonomickou entitou a že jejich provoz ani ochrana přírody nejsou možné bez politické podpory a finančních zdrojů. Zoo se snaží nabýt udržitelné podoby, v níž nebudou závislé jen na př́jmu ze vstupného (Meuser, 2019). Jde o součást procesů edukace, tematizace i komercionalizace. Antropomorfismus však v sobě zahrnuje i obecnější srovnání mezi zviřaty a návštěvníky a může být cenným vzdělávacím nástrojem (technikou), jak přiblí̌it člověka a zvíre. Opodstatnění má nicméně jen dobře informovaný (vzdělávací) antropomorfismus (Kleiman, Thompson \& Baer, 2010).

Tradiční městské zoologické zahrady s nedostatkem prostoru se $v$ průběhu svého vývoje více specializují a snižují počty druhů a také počty expozic, které se díky tomu mohou zvětšovat a nabízet zvíratům přirozenější prostředí a welfare. $V$ některých zoo Ize tento trend také vysledovat ve sloganech, jimiž dávají tyto proměny symbolicky najevo (Více prostoru pro méně zvířat - Halle, Bern). Později vzniklé zoo mohou naopak své kolekce vzhledem k dostatečné rozloze stále rozšiřovat. Zároveň vznikají zařizení nová, takže počet zoo dále roste. Jsou většinou menší a často specializovaná na určitou skupinu zvířat - např́iklad ptači parky či farmaparky (zoo hospodářských zviřat), v nichž sílí dưraz na kontakt člověka a zviŕ̌ete i ochranu vzácných plemen. Jiné mají podstatu všeobecné zoo více připomínající někdejší menažerie, $v$ nichž o ochraně přírody a tímto směrem zaměřeném vzdělávání nemůže být řeč. $V$ budoucnu mohou některé zaniknout a jiné dorůst do podoby klasické zoologické zahrady. Průběžně dochází k další koevoluci tohoto sociálního konstruktu. Právě prezentace historie zoo může mít rovněž značný vzdělávací potenciál reflektující vztah člověka a přírody.

\section{Závěr}

Zoo jsou místem, v němž se dají studovat mnohé kulturní, vědecké, sociální a politické aspekty a koncepty. Jsou samy o sobě prismatem, jakým se lidstvo dívalo a dívá na př́rodu a živé organismy. Jedním z nejsilnějších antropocentrických konceptů spojených se zoo je síla a moc (nad prírodou i lidmi). Objevovala se a objevuje $v$ mnoha podobách - fyzických, vizuálních či symbolických. Faktorů ovlivňujících podobu zoo je však mnohem více (obr. 1). Na všechny je navíc nutné nahlížet v určitém geografickém kontextu. Současný stav zoo je reflexí vývoje, který se eklekticky zaznamenával do jejich podoby. Ve vybraných zoo vznikají ekocentricky (holisticky) pojaté areály, v nichž se návštěvníci vnořují do př́rody (princip imerze). $V$ rámci celistvého pojetí se však zároveň zvyšuje význam lidských prvků - etnografizace se symbolickým významem. Diskutabilní je také antropomorfní prístup ke zviŕatům, kontakt s nimi a komercionalizace prezentovaných témat. Ač mohou trendy ve vývoji zoo působit protikladně či kontroverzně, všechny mají své klady a zápory. Velký důraz na zážitky může přispět k aktivnímu vzdělávání, ale zároveň zoo stojí před rizikem, aby se nedostaly zpět do postavení institucí primárně pro lidi a pouze sekundárně pro zvířata (Frost, 2011). Ve vědecky řízených zoo dochází ke klíčovému propojování jejich funkcí - $v$ ideálním př́padě do ochranářského edutainmentu, tedy do vzdělávání zábavně a aktivizačně směřujícímu a nabádajícímu k ochraně přírody a životního prostředí. Zoo se musí snažit vybalancovat zábavní, resp. rekreační a výzkumně vzdělávací funkce.

Rozdíly mezi zoo jsou však větší než kdy dřiv, a z toho vyplývá taky diametrálně odlišné možnosti a uplatnění environmetálního vzdělávání. Je zcela zřejmé, že vzdělávání v prostředí skládajícího se pouze z malých klecí je zcela odlišné než v případě naturalistického prostředí imitujícího přirozené či alespoň přirodní prostředí. Základním prvkem úspěchu moderních zoo jsou lidé (Frost, 2011) poznání chtiví návštěvníci i erudovaní zaměstnanci - a na vzdělávání i potřeby zvířat myslící expoziční design (Yilmaz, Düzenli, \& Çiğdem, 2017). Na zoo jako takové jsou kladeny větší nároky, ale zároveň jsou navštěvovanější víc než kdy dřív. Přes všechny změny ve společnosti, které za více než 200 let existence moderních zoo proběhly, nejsou dosud nahraditelné. Musí však stále pokračovat ve vývoji odpovídajícím vývoji společnosti, aby jejich existence byla opodstatněna a aby přispívaly (vzděláváním i jinými aktivitami) ochraně prírody a prostředí. Stále $v$ nich má zastoupení pojetí antropocentrické, u některých vědecky orientovaných jej již doplňuje i to biocentrické až ekocentrické. 


\section{Reference}

- Axelsson, T., May, S. (2008). Constructed Ladscapes in Zoos and Heritage. International Journal of Heritage Studies, 14(1), 43-59. https://doi.org/10.1080/13527250701712356

- Baratay, E. \& Hardouin-Fugier, E. (2004). ZOO: a history of zoological gardens in the West. Reaktion books.

- Barnhill, D. (2010). Key Terms in Environmental Philosophy. University of Wisconsin Oshkosh. https://www.uwosh.edu/facstaff/barnhill/490-docs/thinking/terms (23. 2. 2021)

- Beardsworth, A., \& Bryman, A. (2001). The wild animal in late modernity: The case of the Disneyization of zoos. Tourist Studies, 1(1), 83-104.

https://doi.org/10.1177/146879760100100105

- Benbow, S. M. P. (2000). Zoos: Public Places to View Private Lives. Journal of Popular Culture, 33(4), 13-23. https://doi.org/10.1111/j.0022-3840.2000.3304_13.

- Borgards, R. (Ed.). (2016). Tiere: Kulturwissenschaftliches Handbuch. J. B. Metzler Verlag.

- Carr, N., \& Cohen, S. (2011). The Public Face of Zoos: Images of Entertainment, Education and Conservation. Anthrozoös, 24(2), 175-189.

https://doi.org/10.2752/175303711X12998632257620

- Catibog-Sinha, C. (2008). Zoo Tourism: Biodiversity Conservation Through Tourism. Journal of Ecotourism, 7(2-3), 160-178. https://doi.org/10.2167/joe-0229.0

- Coe, J. C. (1986). Towards a Co-Evolution of Zoos, Aquarium and Natural History Museums. In AAZPA 1986 Annual Conference Proceedings (pp. 366-376). American Association of Zoological Parks ans Aquariums.

- Dittrich, L. (2000). Die Geschichte der Zoologischen Gärten in Deutschland. In Zootierhaltung: Grundlagen (7. völlig überarb.). Verlag Harri Deutsch.

- Dobroruka, L. a kol. (1989). Zoologické zahrady. Státní pedagogické nakladatelství.

- Dollinger, P. (2012). Gärten für Tiere - Erlebnise für Menschen. J.P. Bachem Verlag.

- Durrell, G. (2001). Zakotvená archa. Jiří Buchal - B B art.

- Frost, W. (2011). Zoos and Tourism: Conservation, Education, Entertainment?. Channel View Publications, Aspects of tourism.

- Gipps, J. (2014). Zoos past, present and future: from royal gifts to biodiversity conservation. In McGregor Reid, G. \& Moore, G., History of Zoos and Aquariums: From Royal Gifts to Biodiversity Conservation (pp. 154-158). North of England Zoological Society.

- Godinez, A., \& Fernandez, E. J. (2019). What is the zoo experience? How zoos impact a visitor's behaviors, perceptions, and conservation efforts. Frontiers in Psychology, 10, 1-8. https://doi.org/10.3389/fpsyg.2019.01746

- Goronzy, F. (2003). Die Inszenierung des Paradieses: Eine qualitative Inhaltsanalyse von künstlichen Erlebniswelten. Diplomarbeiten Agentur diplom.de.

- Grazian, D. (2017). American Zoo: A sociological safari. Princeton University Press.

- Hancocks, D. (2001). A different nature: the paradoxical world of zoos and their uncertain future. University of California Press. 
- Hoage, R. J., \& Deiss, W. A. (1996). New worlds, new animals: from menagerie to zoological park in the nineteenth century. Johns Hopkins University Press.

- Holtorf, C. (2008). Zoos as Heritage: An Archaeological Perspective. International Journal of Heritage Studies, 14(1), 3-9. https://doi.org/10.1080/13527250701711994

- Hyson, J. (2000). Jungles of Eden: The Design of American Zoos. In Conan, M., Environmentalism in Landscape architecture (pp. 23-44). Dumbarton Oaks Colloquium on the History of Landscape Architecture XXII.

- Kalof, L. (2007). Looking at Animals in Human History. Reaktion Books.

- Kean, H., \& Howell, P. (2018). The Routledge companion to animal-human history. Routledge.

- Kelly, J. D. (1997). Effective conservation in the twenty-first century: The need to be more than a zoo. An organisation's approach. International Zoo Yearbook, 35, 1-14.

- Koebner, L. (1994). Zoo Book: The Evolution of Wildlife Conservation Centers. Tom Doherty Associates.

- Kisling, V. N. (2001). Zoo and aquarium history: ancient animal collections to zoological gardens. CRC Press.

- Kleiman, D. G., Thompson, K. V., \& Baer, C. K. (2010). Wild animals in Captivity: Principles \& Techniques for Zoo Management. The University of Chicago Press.

- Kopnina, H. (2018). Anthropocentrism and Post-Humanism. In Callan, H. (ed) The International Encyclopedia of Anthropology. Wiley.

- Lemke, K. (1987). Tiergärten. Zoos, Aquarien, Wildgehege. VEB Tourist Verlag.

- Lindholm, J. (2013). Zoo History. In M. D. Irwin, J. B. Stoner, \& A. M. Cobaugh (Eds)., Zookeeping: an introduction to the science and technology (pp. 31-42). The University of Chicago Press.

- Linhart, J. a kol. (2004). Slovník cizích slov pro nové století. Dialog.

- Macho, T. (2005). Zoologiken. Tierpark, Zirkus und Freakshow. In Theile, G., Anthropometrie: Zur Vorgeschichte des Menschen nach Maß (pp. 155-177). Wilhelm Fink.

- May, C. K. (2020). Die Szenografie der Wildnis: Immersive Techniken in zoologischen Gärten im 20. und 21. Jahrhundert. Neofelis Verlag UG.

- Meuser, N. (2019). Zoo Buildings: Construction and Design Manual. DOM publishers.

- Mizicko, L., \& Bell, E. C. (2001). Encyclopedia of the World's Zoos. Fitzroy Dearborn Publishers.

- Nekolný, L. (2020). Zoo jako místa šiřrení udržitelnosti. Regionální rozvoj mezi teorií a praxí, 9(2), 14-26.

- Nekolný, L. (2021). Proměny chovu exotických zvířat v evropských zoo. Geografické rozhledy, 30(3), 26-29.

- Nekolný, L., \& Fialová, D. (2018). Zoo Tourism: What Actually Is a Zoo? Czech Journal of Tourism, 7(2), 153-166. https://doi.org/10.1515/cjot-2018-0008 
- Osayimwese, I. I. (2016). Armchair safaris: Representations of African culturs in zoos. Architectural-Theory Review, 20(3), 296-311. https://doi.org/10.1080/13264826.2016.1195853

- Parker, M. (2020). The genealogy of the zoo: Collection, park and carnival. Organization. 1-17. https://doi.org/10.1177/1350508420910573

- Patrick, P. G., \& Tunnicliffe, S. D. (2013). Zoo Talk. Springer.

- Poley, D. (1993). Berichte aus der Arche: Nachzucht statt Wildfang. Trias.

- Probyn-Rapsey, F. (2018). Anthropocentrism. In Gruen, L. (Ed). Critical terms for Animal Studies (pp. 47-63). The University of Chicago Press.

- Rabb, G. B. (2004). The evolution of zoos from menageries to centers of conservation and caring. Curator, 47(3), 237-246. https://doi.org/10.1111/j.2151-6952.2004.tb00121.x

- Rae, G. (2014). Heidegger's influence on posthumanism: The destruction of metaphysics, technology, and the overcoming of anthropocentrism. History of Human Sciences, 27(1), 51-69. https://doi.org/10.1177/0952695113500973

- Rees, P. A. (2011). An introduction to zoo biology and management. Wiley-Blackwell.

- Ross, S. R., \& Gillespie, K. L. (2008). Influences on Visitor Behavior at a Modern Immersive Zoo Exhibit. Zoo Biology, 0, 1-11. https://doi.org/10.1002/zoo.20220

- Steinecke, A. (2009). Themenwelten im Tourismus: Marktstrukture - Marketing-Management - Trends. Oldenbourg.

- Steinkrüger, J.-E. (2013). Thematisierte Welten: über Darstellungspraxen in zoologischen Gärten und Vergnügungsparks. Transcript.

- Ullmann, P. (2019). Slon v architektuře. O navrhování zoologických zahrad. Kant.

- Urban, L. (2017). Sociologie: klíčová témata a pojmy. Grada.

- Van Reybrouck, D. (2005). Archaeology and urbanism: railway stations and zoological gardens in the 19th-century cityscape. Public Archaeology, 4(4), 225-241.

https://doi.org/10.1179/pua.2005.4.4.225

- Van Vliet, E. (2015). Exhibiting Zoo Animals. Schüling Verlag.

- Woods, B. (1998). Animals on display: Principles for interpreting captive wildlife. The Journal of Tourism Studies, 9(1), 28-39. https://researchonline.jcu.edu.au/39155/1/39155woods-1998.pdf

- Woods, A. (2018). Doctors in the Zoo. In Woods, A., Bresalier, M., Cassidy, A. et al. (eds). Animals and the Shaping of Modern Medicine (pp. 27-62). Springer Nature/Palgrave Macmillan.

- Yilmaz, S., Düzenli, T., \& Çiğdem, A. (2017). Current World Environment, 12(1). http://dx.doi.org/10.12944/CWE.12.1.03 